\title{
Hydraulic Models for Calculating Head Loss in Water Distribution System: a case study in Konya
}

\author{
Kağan Eryürük ${ }^{1 *}$ \\ ${ }^{1 *}$ Necmettin Erbakan University, Faculty of Engineering, Departmant of Civil Engineering, Konya, Turkey, (ORCID: 0000-0003-3993-839X), \\ kaganeryuruk@gmail.com
}

(1st International Conference on Applied Engineering and Natural Sciences ICAENS 2021, November 1-3, 2021)

(DOI: 10.31590/ejosat.996991)

ATIF/REFERENCE: Eryürük, K. (2021). Hydraulic Models for Calculating Head Loss in Water Distribution System: a case study in Konya. European Journal of Science and Technology, (28), 275-279.

\begin{abstract}
The management of the water supply system becomes crucial day by day because of limited natural water sources and rapidly increasing population all over the world. However, the water distribution systems have various technical problems and the energy loss in the system can be counted one of these problems. In this study, the water distribution system of a designated area in the Yaka district of Konya was examined using Hardy-Cross method and, the hydraulic simulation softwares EPANET, and WaterCAD which are used in hydraulic modeling of the water distribution systems frequently. The same data of designated area were used for EPANET and WaterCAD in the study. The calculations demonstrated that the head loss calculated in EPANET is 3.5\% and \%16.2 lower than that calculated by WaterCAD and Hardy-Cross, repectively when PVC pipes were used in the water network. When polyethelene pipes were used in the water network, the head loss calculated in EPANET is 3.8\% and \%26.6 lower than that calculated by WaterCAD and Hardy-Cross, repectively. In the case of choosing WaterCAD and Hardy-Cross as the model for water distribution system, the project cost would increase slightly due to increasing the diameter of the pipes for reducing the head loss. It can be concluded that by comparing the head losses, EPANET is more efficient than WaterCAD and Hardy-Cross.
\end{abstract}

\section{Su Dağıtım Sisteminde Yük Kaybını Hesaplamak için Hidrolik Modeller: Konya'da bir örnek çalışma}

\begin{abstract}
$\ddot{O} \mathbf{z}$
Sınırlı doğal su kaynakları ve tüm dünyada hızla artan nüfus nedeniyle su temin sisteminin yönetimi her geçen gün önemli hale gelmektedir. Ancak su dağıtım sistemlerinin çeşitli teknik sorunları vardır ve sistemdeki enerji kaybı bu sorunlardan biri sayılabilir. Bu çalışmada, Konya ili Yaka ilçesinde belirlenmiş bir alanın su dağıtım sistemi Hardy-Cross yöntemi ve su dağıtım sistemlerinin hidrolik modellemesinde sıklıkla kullanılan hidrolik simülasyon yazılımları EPANET ve WaterCAD kullanılarak incelenmiştir. Çalışmada EPANET ve WaterCAD için belirlenen alanın aynı verileri kullanılmıştır. Hesaplamalar, EPANET'te hesaplanan yük kaybının, su şebekesinde PVC borular kullanıldığında sırasıyla WaterCAD ve Hardy-Cross tarafından hesaplanandan \%3,5 ve \%16,2 daha düşük olduğunu göstermiştir. Su şebekesinde polietilen borular kullanıldığında, EPANET'te hesaplanan yük kaybı WaterCAD ve Hardy-Cross tarafından hesaplanandan sırasıyla \%3,8 ve \%26,6 daha düşük olarak bulunmuştur. Su dağıtım sistemi için model olarak WaterCAD ve Hardy-Cross seçilmesi durumunda, yük kaybını azaltmak için boru çapının artırılması gerektiğinden proje maliyeti bir miktar artacaktır. Yük kayıpları karşılaştırıldığında, EPANET'in WaterCAD ve Hardy-Cross'tan daha verimli olduğu sonucuna varılabilir.
\end{abstract}

Anahtar Kelimeler: EPANET, Hardy-Cross, Model, WaterCAD, Su dağıtım sistemi.

*Corresponding Author: kaganeryuruk@gmail.com 


\section{Introduction}

Providing the appropriate quality water sufficiently is one of the crucial issues in human history because of the importance of water to the life. Hence, the water distribution systems were built to achieve this aim. However, design of a water distribution system has many technical problems. Therefore, recently, an increasing number of hydraulic models to describe water distribution systems have been reported by many researchers to improve the performance of these infrastructures [1-3].

Many small- scale water supply projects in Turkey are made using the dead end method in water distribution systems by Iller Bankasi. However, there are some other methods for modeling water distribution systems to compare the energy loss. One of these methods is Hardy-Cross method that is applicable to closed-loop pipe networks. In this method, an iterative procedure is used to calculate the energy loss in the water distribution system. Topacik and San have studied the comparison of equivalent pipe and Hardy-Cross methods [4] and Lopes has developed a program for designing the water distribution system using the Hardy-Cross method [5]. Furthermore, especially, energy loss in water distribution system can be calculated using softwares by modeling and comparing the head loss for each system. One of these softwares is WaterCAD that is developed by Bentley Systems, Incorporated, Exton, PA, United States. The gradient algorithm is used in WaterCAD and particular energy equations and nodal equations are taken consideration for each pipes and nodes for both heads of nodal and pipe flow [6]. In WaterCAD, moduls like Darwin Calibrator, Darwin Designer, Skelebrator and SCADAConnect helps users to make the project more specific and presents special solution ways.

Recently, WaterCAD was used by researchers to plan and evaluate the performance of water distribution system and to model the formation of the chemicals in the system [7-10]. Another method for modeling the water distribution systems is EPANET software which is open-structured and developed by the United States Environmental Protection Agency (USEPA). In EPANET software, the head loss equations are based on Newton-Raphson iteration method to solve the simultaneous equations which are derived from the flow and head loss in the water distribution system. Some researchers were used EPANET to model the water distribution system, to reduce the energy cost, to optimize the leakage and calibrate the water distribution system, and to model the residuals of chemicals in water networks [11-15].

In this study, it has been studied to compare the head losses in the water distribution system using Hardy-Cross method and different hydraulic models to operate the water distribution system more efficiently and at lower cost by achieving minimum head loss.

\section{Material and Method}

A region, which covers an area of $45000 \mathrm{~m}^{2}$ is located in Yaka Neighborhood of Meram district of Konya, Turkey, was selected for hydraulic modeling (Fig. 1). The elevations in the chosen region vary between $1167 \mathrm{~m}$ and $1106 \mathrm{~m}$. The water demand of the region, which was calculated as daily and hourly by taking into consideration of population of the chosen region, is met from a $5000 \mathrm{~m}^{3}$ reservoir.

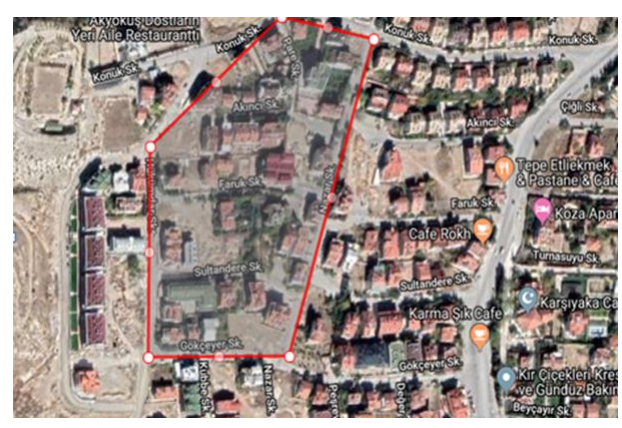

Figure 1. Satellite image of the region

Table 1 indicates the data used in this study. The data was provided from Metropolitan Municipality of Konya. MS Excel was used for the calculations of the modeling the water distribution system using the Hardy-Cross method. Hardy-Cross method consists of predicting the flow rates in each pipe of the network and then correcting the estimated flow rates until the pressures are balanced.

The same data was also used for calculations in EPANET and WaterCAD as shown in Table 1.

Table 1. The data of the chosen region

\begin{tabular}{|c|c|c|c|}
\hline $\begin{array}{c}\text { Given names of } \\
\text { pipes and } \\
\text { numbers }\end{array}$ & $\begin{array}{c}\text { Length } \\
\text { of the } \\
\text { pipe (m) }\end{array}$ & $\begin{array}{c}\text { Diameter } \\
\text { of the } \\
\text { pipe }\end{array}$ & $\begin{array}{c}\text { Material of } \\
\text { pipe }\end{array}$ \\
\hline$T-A(0)$ & 105 & 200 & $\begin{array}{c}\text { PVC- } \\
\text { Polyethylene }\end{array}$ \\
\hline$A-B(1)$ & 142.5 & 100 & $\begin{array}{c}\text { PVC- } \\
\text { Polyethylene }\end{array}$ \\
\hline$C-D(2)$ & 116 & 80 & $\begin{array}{c}\text { PVC- } \\
\text { Polyethylene }\end{array}$ \\
\hline$E-F(3)$ & 213 & 80 & $\begin{array}{c}\text { PVC- } \\
\text { Polyethylene }\end{array}$ \\
\hline$G-H(4)$ & 138 & 80 & $\begin{array}{c}\text { PVC- } \\
\text { Polyethylene }\end{array}$ \\
\hline$I-J(5)$ & 122 & 80 & $\begin{array}{c}\text { PVC- } \\
\text { Polyethylene }\end{array}$ \\
\hline$A-C(6)$ & 57 & 150 & $\begin{array}{c}\text { PVC- } \\
\text { Polyethylene }\end{array}$ \\
\hline$B-D(7)$ & 91 & 80 & $\begin{array}{c}\text { PVC- } \\
\text { Polyethylene }\end{array}$ \\
\hline$C-E(8)$ & 77.5 & 150 & $\begin{array}{c}\text { PVC- } \\
\text { Polyethylene }\end{array}$ \\
\hline$D-F(9)$ & 125 & 80 & $\begin{array}{c}\text { PVC- } \\
\text { Polyethylene }\end{array}$ \\
\hline$E-G(10)$ & 40.5 & 150 & $\begin{array}{c}\text { PVC- } \\
\text { Polyethylene }\end{array}$ \\
\hline$F-H(11)$ & 43 & 80 & $\begin{array}{c}\text { PVC- } \\
\text { Polyethylene }\end{array}$ \\
\hline$G-I(12)$ & 72 & 150 & $\begin{array}{c}\text { PVC- } \\
\text { Polyethylene }\end{array}$ \\
\hline$H-J(13)$ & 55 & 80 & $\begin{array}{c}\text { PVC- } \\
\text { Polyethylene }\end{array}$ \\
\hline
\end{tabular}


Two types of pipes, which were PVC and polyethylene, were used in the study. The number and the length of the pipes were 14 and $1397.5 \mathrm{~m}$, respectively. In EPANET, initially, the tank and nodes were located in the working area depending on their coordinates and ground elevations. Then, the pipes were placed in accordance with the network in the region and their properties were entered (diameter, roughness coefficient). Hourly water consumption data calculated according to population were given to the nodes and hydraulic simulation was run (Fig. 2). The energy loss in polyethylene pipe was also calculated for both methods.

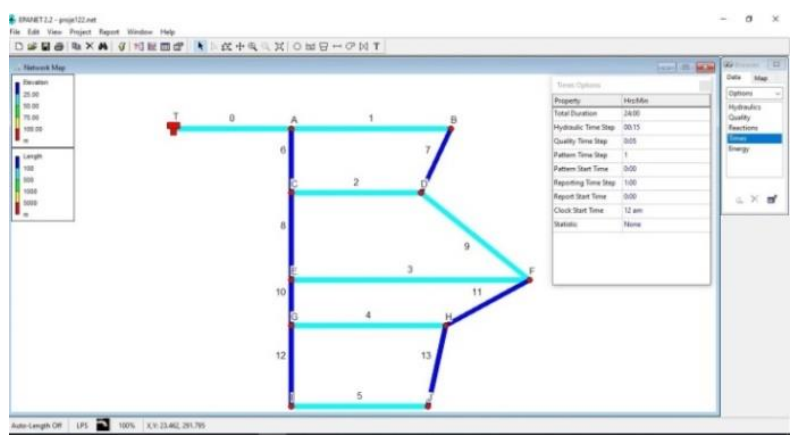

Figure 2. Image of EPANET software

In WaterCAD, first, the tank and the nodes were placed accordance to their coordinates and ground elevations in chosen area as designated previously. Then, the pipes were located in the network. The diameters of the pipes were introduced to the software and the roughness coefficient was determined by software depending on material type of the pipes. The water consumption data was introduced to the nodes and hydraulic simulation was run (Fig. 3). The simulation was run over a period of 24 hours. Adjustments were made to update hydraulic data every fifteen minutes by software

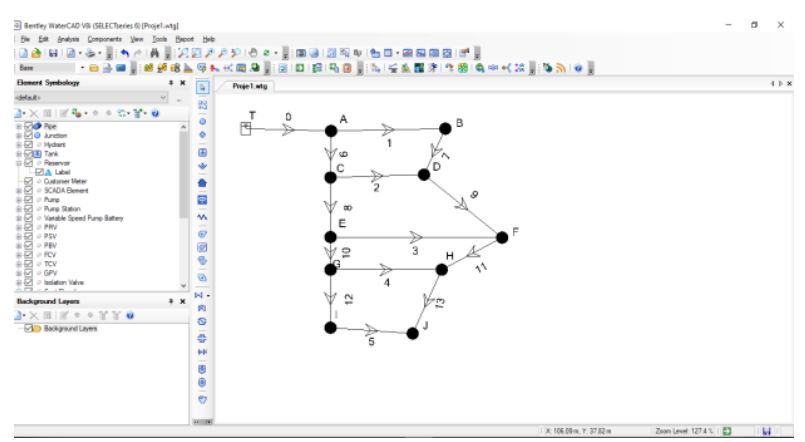

Figure 3. Image of WaterCAD software

All calculations were carried out using Darcy Weisbach equation. Friction factor (f) is used to calculate the friction head loss $\left(h_{f}\right)$ in Darcy Weisbach equation [16]. The friction head loss was identified as below [16];

$h_{f}=f \frac{L V^{2}}{D 2 g}$

where $\mathrm{D}=4 \mathrm{~A} / \mathrm{P}$ denotes the hydraulic diameter of the pipe (A and $\mathrm{P}$ denote cross-sectional area and wetted perimeter, respectively), $\mathrm{L}$ denotes the length of the pipe, $\mathrm{V}$ denotes average flow velocity, and $\mathrm{g}$ denotes the acceleration due to gravity.

The head loss in PVC pipe and polyethylene pipe were calculated for all methods.

\section{Results and Discussion}

Comparison of the head losses in the water distribution system of a designated area was performed using Hardy-Cross method and different hydraulic models in this study.

The results indicated that the head loss in each PVC pipe differed depending on the model used (Figure 4).

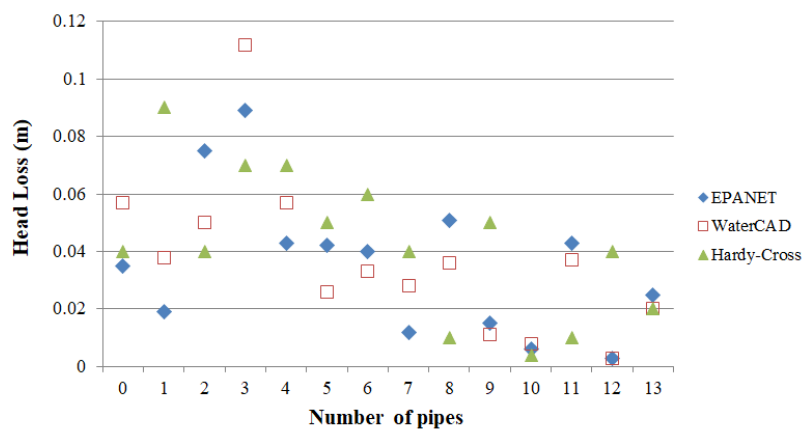

Figure 4. Head loss in each PVC pipe

The total head loss for chosen region using PVC pipes was calculated as $0.498 \mathrm{~m}, 0.516 \mathrm{~m}$, and $0.594 \mathrm{~m}$ for EPANET, WaterCAD, and Hardy-Cross respectively (Figure 5). In other words, the total head loss was obtained 3.5\% and \%16.2 less in EPANET than in WaterCAD, Hardy-Cross, respectively. It could be said that the lowest head loss was achieved using EPANET.

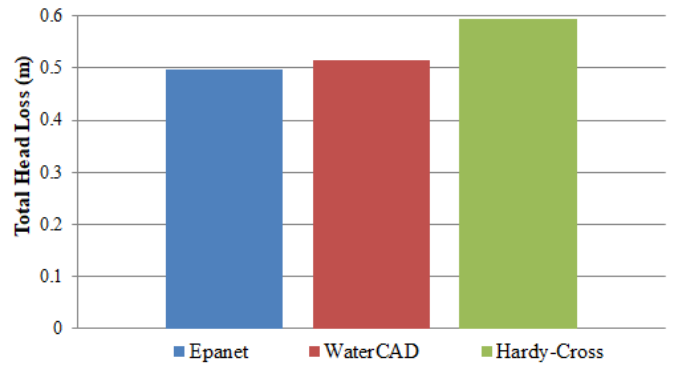

Figure 5. Total head loss for each model for PVC pipes

When polyethylene pipes were used in the water distribution system, the head loss for each pipe in EPANET and WaterCAD was calculated similar (Figure 6).

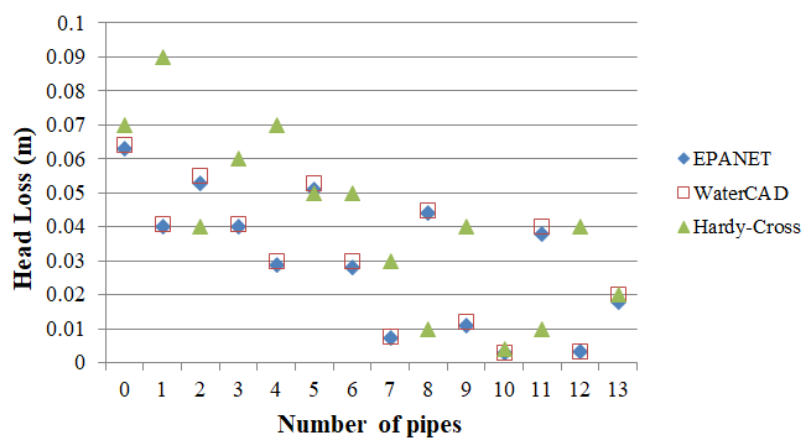

Figure 6. Head loss in each polyethylene pipe 
The total head loss was $0.429 \mathrm{~m}, 0.445 \mathrm{~m}$, and $0.584 \mathrm{~m}$ for EPANET, WaterCAD, and Hardy-Cross respectively (Figure 7). The total head loss was obtained $3.8 \%$ and \%26.6 less in EPANET than in WaterCAD, Hardy-Cross, respectively.

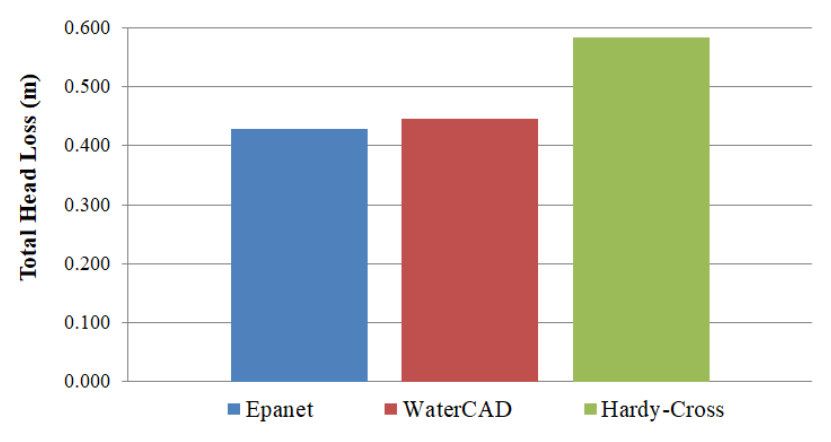

Figure 7. Total head loss for each model for polyethylene pipes

It is observed that the total head loss decreased $13.9 \%$ in EPANET, $13.8 \%$ in WaterCAD, $1.7 \%$ in Hardy-Cross when the polyethylene pipes were used instead of PVC pipes (Figure 8).

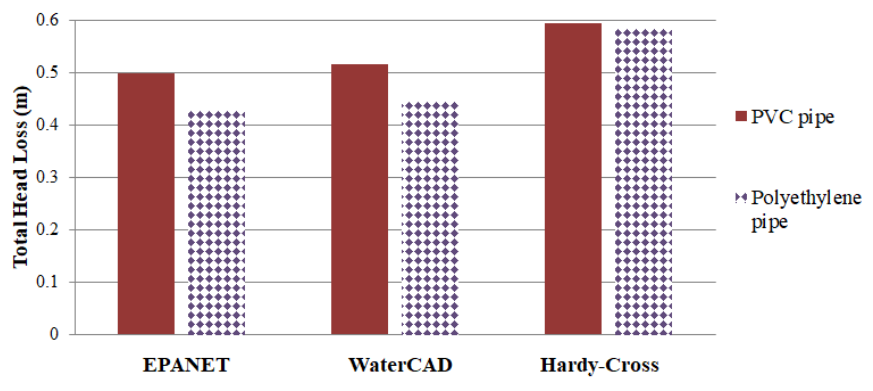

\section{Figure 8. The change in total head loss depending on pipe} material for models

The lowest head loss was obtained using EPANET with polyethylene pipes used in water distribution system (Figure 8).

The changes in head loss depending on each model were obtained in this study. A number of pipes in the system could be inadequate that cause very high velocities at some points in the system where nodal demands were high. This situation would be result in huge pipe leakages and bursts in the distribution system. Hence, the system performance would be reduced.

Moreover, inadequate reservoir height could be one of the reasons for difference head loss values between modes to give rise to negative pressures within the distribution system.

\section{Conclusions and Recommendations}

The head loss in water distribution system in a designated area was modeled using EPANET, WaterCAD, and Hardy-Cross in this study. In the lights of results, considering the head loss, it can be said that a water distribution system modeled with EPANET will work more efficiently and can be operated at a lower cost. Moreover, EPANET is free software, so this is also an advantage for the users.
If the same water distribution system is modeled with WaterCAD and the head loss is desired to be at the same level, the diameter of pipes would be increased in order to reduce the energy loss and the cost of the water distribution system would increase.

Using Hardy-Cross method to calculate head loss in the water distribution system will result in the highest head loss and in turn the cost of the system would be the highest one. It can also be said that choosing polyethylene pipes instead of PVC pipes will reduce the cost because polyethylene pipes cause lower head loss comparing to PVC pipes.

\section{References}

[1] Adnan M. Abu-Mahfouz, Yskandar Hamam, Philip R. Page, Kazeem B. Adedeji, Amos O. Anele and Ezio Todini. RealTime Dynamic Hydraulic Model of Water Distribution Networks, Water, vol. 11, no: 3, article no. 470, 2019.

[2] Orazio Giustolisi. Enhanced WDN hydraulic modelling detection of burst leakages, Procedia Engineering, vol. 162, pp. 3-14, 2016.

[3] Selami Kara, I. Ethem Karadirek, Ayse Muhammetoglu, Habib Muhammetoglu. Hydraulic modeling of a water distribution network in a tourism area with highly varying characteristics, Procedia Engineering, vol. 162, pp. 521-529, 2016.

[4] Topacık, D. ve San, H.A. Hardy-Cross ve Eşdeğer boru metotları mukayesesi, DSİ Bülteni, Sayı 58, 1985.

[5] Lopes, A.M.G. Implimentation of the Hardy-Cross Method for the Solution of Piping Networks. Computer Application in Engineering Education. Wiley Periodicals, vol. 12, pp. 117-125, 2004.

[6] Izinyon, O.C., Anyata, B.U., Water Distribution Network Modelling of A Small Community Using Watercad Simulator, Global Journal of Engineering Research, vol. 10, no. 1-2, pp. 35-47, 2011.

[7] Septiawati, E., Sutriyono, E., Juliantina, I., Siswanto, A., Evaluation of Design Planning Water Distribution System with Watercad v.7.0 Simulation Program for Townsite Basecamp Settlement Relocation in Tanjung Enim, South Sumatra, Symposium of Emerging Nuclear Technology and Engineering Novelty (Senten 2018), vol. 1198, article no. 082022, 2019.

[8] Agunwamba, JC., Ekwule, O.R., Nnaji, C.C., Performance evaluation of a municipal water distribution system using WaterCAD and Epanet, Journal of Water Sanitation and Hygiene for Development, vol. 8, no. 3, pp. 459-467, 2018.

[9] Farghaly, A.M., Ahmed, A.M., Gad, A.A., Hashem, M.A., A study for producing drinking water with safe trihalomethane concentrations, Clean Technologies and Environmental Policy, vol. 16, no. 5, pp. 808-818, 2014.

[10]Chang, E.E., Guo, H.C., Li, I.S., Chiang, P.C., Huang, C.P., Modeling the formation and assessing the risk of disinfection by-products in water distribution systems, Journal of Environmental Science and Health Part A-Toxic/Hazardous Substances \& Environmental Engineering, vol. 45, no. 10, pp. 1185-1194, 2010.

[11]Maskit, M., Otsfeld, A., Multi-Objective Operation-Leakage Optimization and Calibration of Water Distribution Systems, Water, vol. 13, no. 11, article no. 1606, 2021.

[12]Babel, M.S., Shrestha, A., Anusart, K., Shinde, V., Evaluating the potential for conserving water and energy in 
the water supply system of Bangkok, Sustainable Cities and Society, vol. 69, article no. 102857, 2021.

[13]Wang, Y., Yok, K.T., Wu, W.Y., Simpson, A.R., Weyer, E., Manzie, C., Minimizing Pumping Energy Cost in Real-Time Operations of Water Distribution Systems Using Economic Model Predictive Control, Journal of Water Resources Planning and Management, vol. 147, no. 11, article no. 102857, 2021.

[14]Garcia-Avila, F., Aviles-Anazco, A., Ordonez-Jara, J., Guanuchi-Quezada, C., del Pino, L.F., Ramos-Fernandez, L., Modeling of residual chlorine in a drinking water network in times of pandemic of the SARS-CoV-2 (COVID-19), Sustainable Environment Research, vol. 3, no.1, article no. 12, 2021.

[15]Monteiro, L., Carneiro, J., Covas, D.I.C., Modelling chlorine wall decay in a full-scale water supply system, Urban Water Journal, vol. 17, no.8, pp. 754-762, 2019.

[16]Monteiro, L., Carneiro, J., Covas, D.I.C., Experimental and Numerical Determination of the Head Loss of a Pressure Driven Flow through an Unlined Rock-Blasted Tunnel, Water, vol. 20, no.12, article no. 3492, 2020. 